\title{
Improving Mulberry (Morus alba L.) Leaf Yield and Quality to Increase Silkworm Productivity in Northern Luzon, Philippines
}

\author{
Mabel M. Caccam ${ }^{1}$ and Teodoro C. Mendoza ${ }^{2}$ \\ ${ }^{1}$ Sericulture Research and Development Institute, Don Mariano Marcos Memorial \\ State University (DMMMSU), Sapilang, Bacnotan, La Union, Philippines \\ ${ }^{2}$ Crop Science, College of Agriculture, U.P. Los Baños, College, Laguna 4031, \\ Philippines
}

\begin{abstract}
Cocoon silk, a high priced fabric, should be produced in large quantities to meet local and international demands using sustainable farming practices. To determine the effects of planting systems and agroecosystems manipulations on the mulberry growth, leaf yield, and quality for silkworm rearing, six agroecosystems manipulations using pit planting, organic manuring, inorganic fertilization, green and green leaf manuring were evaluated and the best alternative to increase production was selected.

Pit planting method and fertilized with any of the following: (1)100-50$50 \mathrm{~kg} \mathrm{NPK} / \mathrm{ha}+10$ tons manure + green manure + mulch (LEISA I); (2) 50$50-50 \mathrm{~kg} \mathrm{NPK} / \mathrm{ha}+10$ tons manures + green + green leaf manure + mulch (LEISA II); and (3) 10 tons manure + green manure + green leaf manure + mulch (Organic Farming I) gave higher mulberry leaf yields (taller mulberry plants, longer shoots, heavier single leaf weights), higher protein contents, and acceptable range of moisture (high moisture contents for young-age worms and low moisture contents for late-age silkworms). The use of sustainable and organic farming techniques can be a good alternative to conventional farming to improve the productivity of sericulture farms.
\end{abstract}

Keywords: sericulture, agroecosystems, organic farming, low external input sustainable agriculture (LEISA), conventional agriculture, mulberry, pit planting method

Correspondence: M. M. Caccam Address: Don Mariano Marcos Memorial State University-Sericulture Research and Development Institute, Sapilang, Bacnotan, La Union E-mail:caccam_mabel@yahoo.com. DOI: 10.32945/atr3711.2015 


\section{INTRODUCTION}

Sericulture is a declining industry in the Philippines. This is unfortunate since silk is a high-priced commodity domestically and internationally, and the country has favorable climate for silkworm rearing. In Northern Luzon, Philippines, sericulture farmers are confronted with the problems of low mulberry productivity due to low soil fertility, pests, and drought as the farms are mostly rainfed and low silk fabric yield due to low quantity and quality cocoons which in turn is due to low quality of mulberry leaves and sub-optimal rearing methods (Caccam and Mendoza, 2010). Successful sericulture venture starts with the stable production of sufficient quality mulberry leaves as the quantity and also quality of mulberry leaves affect the growth and development of the silkworm. On farm, the growth of the silkworm depends on the quality of mulberry leaves being fed, and this is dependent on the variety, agronomic practices, maturity, position of the leaf, and season (FAO, 1987). Understanding the ecological relationships and processes (nutrient cycling) of the agroecosystems that will lead to the optimal use of sunlight, soil nutrients, and external inputs (Reijntjes et al., 1992) is necessary in improving production with fewer environmental and social impacts (Altieri, 1983). Agricultural practices and systems that seek to optimize the use of locally available materials and exploit the use of natural, ecological resources eventually decrease the use of external inputs as well as improve the farm productivity and income (Basilio, 2005, UNDP, 1995). Nutrient, disease incidence, and management have direct effect on agroecosystem yields (Kumar et al., 2004). An agroecosystem is productive and healthy when a proper balance of crops, seeds, nutrients, sunlight, moisture, and other co-existing organisms or rich growing conditions prevail and when crops remain resistant to stress and adversity (UNDP, 1995).

Successful cocoon production in India has been mainly attributed to good crop maintenance using high amounts of organic manure, proper disinfection, and hygiene in rearing house and more care in silkworm rearing (Dandin et al., 2005). A high yield gap of 30-40 kg/100 dfls from the potential of $60-70 \mathrm{~kg} / 100 \mathrm{dfls}$ in cocoon was mainly due to non-adoption of mulberry pruning practices, no input application in mulberry farm, partial adoption of rearing technologies, insufficient infrastructure for rearing, and distribution of silkworms (Babulal et al., (2005).

In mulberry production, several technologies could be practiced by sericulture farmers to ultimately increase cocoon yield. Deep plowing at 
about $40 \mathrm{~cm}$ deep and the application of organic matter had been done in mulberry fields (Hikari, 1997), and the use of pit system with wider spacing for rainfed farming are widely adopted practices in India (Krishnaswami, 1986). Use of cattle manure and organic residues that are allowed to decompose in the soil (Alvarez et al., 1999) provides favorable soil environment for earthworms and beneficial microorganisms (William et al., 1998), buffers the strong acidity of the soil, improves their productivity, and protects the environment from pollution (Chen et al., 2001).

This study was conducted to determine the effects of planting systems and agroecosystems manipulations on the mulberry growth, leaf yield, and quality for silkworm rearing.

\section{METHODOLOGY}

\section{Location of Study and Description agroecosystems set-up and systems}

The study was conducted at Tinaan, Sta. Maria, Ilocos Sur, Region 1, Northern Philippines(17o21'31.05"N 120"25"52.96"E; elevation $30 \mathrm{ft}$ ) (Figure 1). The area was rain fed upland plain and previously a pasture area. The soil was of sandy loam type with initial soil pH of 6.7 to 7.07 ; OM content of $>2 \%$; P content of 42 to $51 \mathrm{ppm}$ and $\mathrm{K}$ content of 0.63 to .777 $\mathrm{kmole} / \mathrm{kg}$ soil. The climate is Type 1 with two distinct seasons: dry from November to April and wet from May to October. The temperature ranged from $23-320 \mathrm{C}$ while relative humidity ranged from $78-92 \%$ with an average of $86.75 \%$.

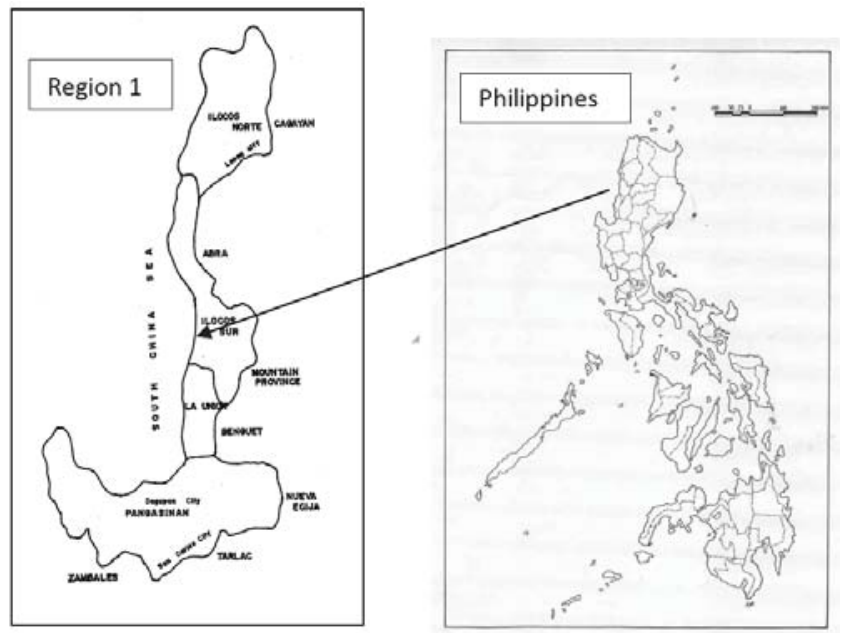

Figure 1. Location of the Study Site. 
The treatments were laid out in Randomized Complete Block Design(RCBD) with three replications. The agroecosystems set-up and systems, planting techniques, and levels of inputs applied are summarized in Table 1.

Table 1. Systems of planting, inorganic (NPK), and organic fertilization rates applied in existing, conventional, LEISA and organic farming treatments.

\begin{tabular}{|c|c|}
\hline Treatment & Description \\
\hline A. Existing Practice & Row Planting + 100-50-50 kg NPK/ha \\
\hline B. Conventional I & Row Planting $+200-50-50 \mathrm{~kg} \mathrm{NPK} / \mathrm{ha}+10$ tons Poultry Manure \\
\hline C. Conventional II & Pit Planting $+200-50-50$ NPK kg/ha +10 tons Poultry Manure \\
\hline $\begin{array}{l}\text { D. Low external input } \\
\text { sustainable agriculture I } \\
\text { (LEISA I) }\end{array}$ & Pit Planting $+100-50-50 \mathrm{NPK} / \mathrm{ha}+10$ tons Poultry Manure + Green Manure \\
\hline $\begin{array}{l}\text { E. Low external input } \\
\text { sustainable agriculture II } \\
\text { (LEISA II) }\end{array}$ & $\begin{array}{l}\text { Pit Planting }+50-50-50 \mathrm{~kg} \mathrm{NPK} \mathrm{kg} / \mathrm{ha}+10 \text { tons Poultry Manure }+ \text { Green } \\
\text { Manure + Green Leaf Manure }+ \text { Mulch }\end{array}$ \\
\hline F. Organic Farming I & $\begin{array}{l}\text { Pit Planting }+10 \text { tons Poultry Manure }+ \text { Green Manure }+ \text { Green Leaf Manure } \\
+ \text { Mulch }\end{array}$ \\
\hline G. Organic Farming II & Pit Planting + Green Manure + Green Leaf Manure + Mulch \\
\hline
\end{tabular}

\section{Mulberry Crop Establishmentand Cultural Management Practices}

Mulberry plants were established following the standard procedure (La Union Techno Guide in Mulberry Production, 1998). For the row system of planting, furrows were set at $1.5 \mathrm{~m}$ apart with plant spacing of 50 $\mathrm{cm}$ within the row. One plant per hill was planted. For pit planting, furrows were set at $1.5 \mathrm{~m}$ apart and plant spacing was 1 meter apart. Holes $50 \mathrm{~cm} \mathrm{x}$ $50 \mathrm{~cm} \times 50 \mathrm{~cm}$ were dug. Organic fertilizer was placed in the hole, covered with thin soil before planting the saplings. Two saplings were planted in the hole to meet the desired plant population as in row spacing.

The legume green manure crops used was mungbean (Vigna radiata), cowpea (V. unguiculata), pigeon pea (Cajanus cajan), katurai (Sesbania grandiflora) and kakawate (Gliricidia sepium). For the green manure treatments, two rows were constructed in between rows of mulberry plants. Mungbean seeds were drilled in two rows at the rate of 18-22 plants per linear meter. Then, these were covered with thin soil. Mungbean pods attained a ratio of 50:50 dried and green; dried pods were harvested and the biomass was mulched on the soil surface. Finally, these were incorporated into the soil during inter-cultivation.

Around each treatment plot, serving as bunds or alleys and in between seven rows of mulberry, rows of kakawate and katurai were planted 
around the plants. In between the rows of mulberry was a row of pigeon pea that was densely planted at 12 plants per linear meter. Some of the plants were allowed to bear fruits for food and for seed for the next cropping season. Pruning started after six months when enough herbage yields were generated; the pruned branchlets and leaves were mulched on the field and were incorporated into the soil at the start of the rainy season.

The area was mulched with corn stalks and weeds in the dry season. These were placed in between inter-rows after transplanting to conserve soil moisture and check the growth of weeds for those with mulch treatments. Weeding started one month after planting. Weeds near the trees were pulled or under-brushed and the weed cuts were placed in between rows of mulberry trees as mulch. Inter-row cultivation followed. Pests and diseases were monitored regularly to identify and control or minimize insect infestation and disease infection. Diseased plants were removed manually and burned to prevent spread of disease.

For the second green manure crop, cowpea seeds were drilled in rows previously occupied by mungbean at two weeks before pruning. This activity was synchronized with the time of harvesting of mulberry leaves. After the cowpea pods (50:50 green: dry pods) and mulberry leaves were harvested, the cowpea biomass was cut down and placed as mulch for the mulberries. At that time, the mulberry plants were again pruned and the inter-rows cultivated, allowing the cowpea biomass to be incorporated into the soil. The kakawate and the katurai were pruned again at six months after first pruning to prevent them from outgrowing and shading the mulberry plants. The biomass was used as mulch to the plants before they were incorporated into the soil.

Organic manure at the rate of 10 tons/ha poultry manure for the first year and five tons/ha poultry manure and five tons/ha silkworm wastes generated from silkworm rearing for the second year were used. For the row and pit plantings, manure was broadcasted and plowed under during inter-row cultivation. Likewise, inorganic fertilizers were dressed at about 10-15 cm along the sides of the plants.

Harvesting was done 60 days after pruning and every two months thereafter. Leaf picking was done for the young-age worms $\left(1^{\text {st }}-3^{\text {rd }}\right.$ instars $)$ while branch cutting was done for the late-age worms. 


\section{Data Gathering}

Data gathering started at one month after planting and continued monthly until one year after establishment. Data were again gathered then every 60 days after pruning in the second year. Ten plants were randomly selected for gathering of the following data in Table 2.

Table 2. Growth and yield indicators and the methods of gathering used in determining the performances of mulberry in Conventional, LEISA, and Organic Farming practices.

\begin{tabular}{|c|c|}
\hline PARAMETERS & METHOD \\
\hline Plant height & $\begin{array}{l}\text { Measured from tallest branch to tip of tallest leaf or shoot. The } \\
\text { plant height was taken monthly in the first year and bi-monthly in } \\
\text { the second year. }\end{array}$ \\
\hline Number of branches & $\begin{array}{l}\text { Number of branches that emerged from the main stem was } \\
\text { counted. }\end{array}$ \\
\hline Length of shoots & $\begin{array}{l}\text { Measured from the base of the branches to the tip of the highest } \\
\text { leaf or shoot. This was taken monthly in the first year and } \\
\text { bimonthly in the second year. }\end{array}$ \\
\hline $\begin{array}{l}\text { Number of } \\
\text { harvestable leaves per } \\
\text { plant }\end{array}$ & $\begin{array}{l}\text { The number of leaves appropriate for feeding silkworm was } \\
\text { counted and recorded starting from 5-6 mos after planting then } \\
\text { after every harvest period. }\end{array}$ \\
\hline $\begin{array}{l}\text { Weight of harvestable } \\
\text { leaves per plant }\end{array}$ & $\begin{array}{l}\text { Harvestable leaves were gathered, weighed, and recorded starting } \\
\text { from 5-6 mo after planting then after every harvest period. }\end{array}$ \\
\hline $\begin{array}{l}\text { Average single leaf } \\
\text { weight }\end{array}$ & $\begin{array}{l}\text { Each leaf emanating from the stem/ branch was weighed } \\
\text { individually and was recorded. }\end{array}$ \\
\hline Mulberry yield/ha & Total leaf yield per plant was weighed after every harvest. \\
\hline
\end{tabular}

Three sample plants were randomly selected for moisture and protein content analysis starting from 45 days after leaf harvesting/stripping, then after every 55 and 65 days to coincide with the leaf harvesting with the age of silkworms in each instars. The leaves from the shoot, leaf suited for $1^{\text {st }}$, $2^{\text {nd }}, 3^{\text {rd }}, 4^{\text {th }}$ and $5^{\text {th }}$ instar larvae, were gathered, weighed, oven-dried, and reweighed to compute the moisture content. Leaf samples from the shoots, suited for young-age and late-age worms, were gathered from all parts of the plants that corresponded to the stage of silkworm larvae.

\section{Data Analysis}

Data collected were analyzed statistically (Combined Analysis in RCBD) to determine the effects of seasons of harvesting, agro-ecosystems manipulation, and their interaction of the growth and yield of mulberry, The DMRT test at $5 \%$ level of significance was used in comparing means of planting systems and agroecosystems manipulations. 
Improving Mulberry Leaf Yield and Quality to Increase Silkworm Productivity

\section{RESULTS AND DISCUSSION}

\section{Growth and Survival of Mulberry Established in the Different Treatments}

Mulberries grown in pit planting (LEISA I and II, and Conventional II) with higher $\mathrm{N}$ applications than the other treatments, had better plant growth from one month after planting up to six months. Organic matter added in dug pit planting led to more water retained in the soil needed by the plants in the dry season. Soil organic matter should be maintained to increase nutrient holding capacity of soil (PCAARRD, 2012). Organic Farming II plants were the shortest but comparable with plants in Existing Practice. The lower N supplied to the plants led to their poor growth. The growth of plants was slow at one to two months; it suddenly increased at two to five months after planting and slowed down or leveled off at six months after planting (Figure 2).

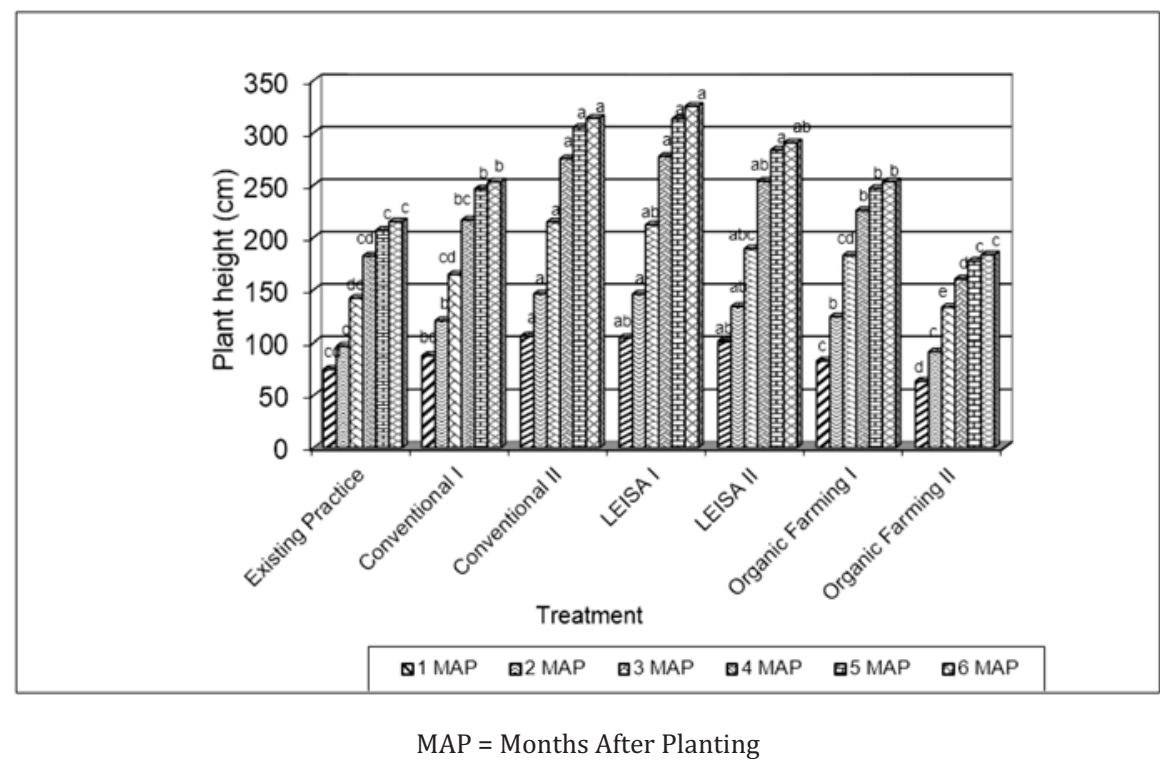

Figure 2. Monthly plant height of mulberry grown in different agroecosystems on its first year of establishment in Sta. Maria, Ilocos Sur.

In the second year, the re-growth of mulberry plants in conventional II was significantly faster (plants were taller) at 15 days to 75 days after pruning. The re-growth of plants in Organic Farming II did not differ 
significantly with Existing Practice. On the $30^{\text {th }}$ to $75^{\text {th }}$ day after pruning, the mulberry plants in Conventional II and LEISA I were similar but significantly bigger from the other treatments because more nitrogen was readily available for growth. Plants grown under Organic Farming II and Existing Practice were smaller (Figure 3).

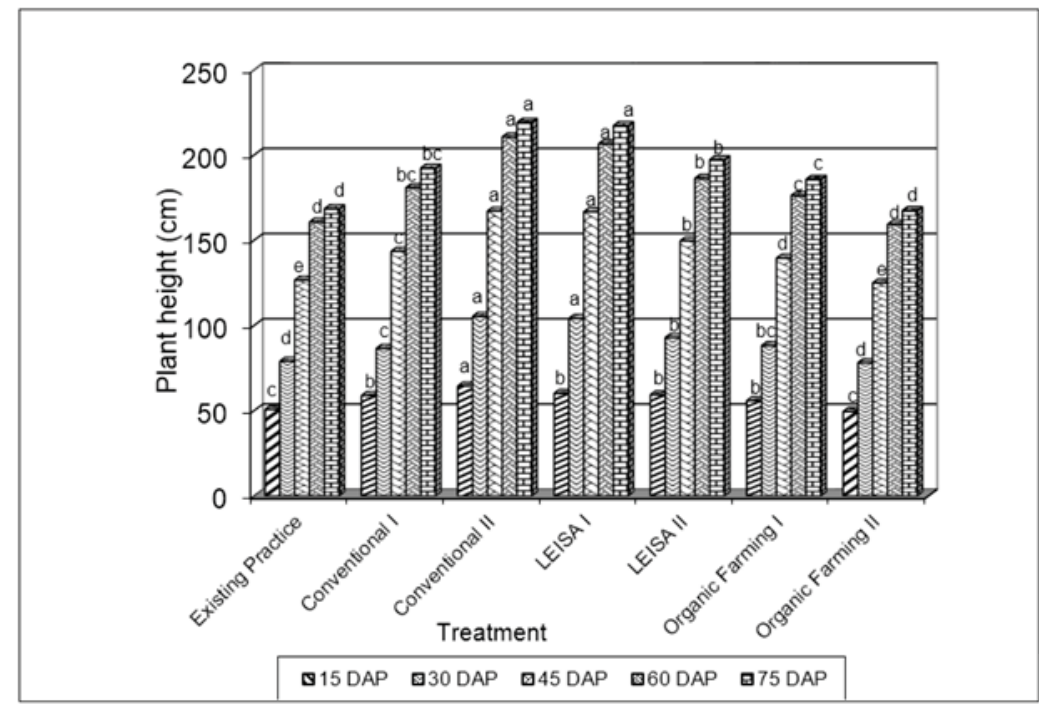

DAP = Days After Pruning

Figure 3. Plant height of mulberry grown in different agroecosystems at different ages of pruning on its second year of establishment in Sta. Maria, Ilocos Sur.

Effect of the Seasons on the Growth and Yield of Mulberry in Its First and Second Year of Establishment

During the first year, the season of harvesting significantly influenced the growth and yield of mulberry. Plants were taller during the rainy months of June to November while the plants formed more branches during the months of April to July. Harvestable leaves were heaviest from January to July while average single leaf weight was significantly highest from June to November (Table 3). In the second year, plants were taller from July to December and April than from January to March. Shoots were significantly longer from July to October than in any other months while the most number of branches was recorded from October to December. The most number of leaves per plant was observed in the July-October and 
April-June harvesting. Harvestable leaves per plant and average single leaf were significantly heavier than the rest of the treatments (Table 4).

\section{Mulberry LeafProductivity in the Different Treatments}

During the first year, three-leaf harvests were done and this increased to four-leaf harvests in the second year. At three-leaf harvests, LEISA I and Conventional II had the highest mulberry leaf yields, followed by Conventional I and LEISA II. The lowest yields were observed in Organic Farming II \& I, and Existing Practice. The lower yields of the Organic I and II and LEISA II were attributable to lower inorganic nitrogen fertilizer applied (Table 5). Though the Organic Farming techniques were provided with mulches, green and leaf manure, the outcome had not been realized during the early months of establishment. In case of mulching with cut grasses, organic mulches, tangible effects cannot be achieved unless more than 1.5 tons of mulch could be used per hectare. The amount of organic matter needed should exceed 18 tons/ha/year and is effective if applied at the end of rainy season (AICAF 1995). Studies have shown, however, that in the first year, inorganic fertilizer treatments gave higher yields than the farmyard manure (FMY). In later years, yields in inorganic fertilizer were lower than the FMY treatment. Income was higher in the farm yard manure treatment (Mansatta, 1999).

Despite lower inorganic fertilization in LEISA I, its substitution with green manure proved beneficial. Since the mulberry yields per unit area are closely related to the number and length of new shoots, it is very important to apply fertilizers to promote the growth of new shoots (AICAF, 1995). In the second year, LEISA I out-yielded all other treatments followed by Conventional II, Conventional I, and LEISA II. Organic Farming II was significantly the lowest, followed by Existing Practice and Organic Farming I. 
ffect of season and agroecosystems on the growth, yield and quality of mulberry in the first year of establishment in Sta. Maria, ocos Sur.

$\begin{array}{lllllll}\begin{array}{l}\text { Plant Height } \\ (\mathrm{cm})\end{array} & \begin{array}{l}\text { Length of } \\ \text { Shoots } \\ (\mathrm{cm})\end{array} & \begin{array}{l}\text { Number of } \\ \text { Branches/Plant }\end{array} & \begin{array}{l}\text { Number of } \\ \text { Leaves/Plant }\end{array} & \begin{array}{l}\text { Weight of } \\ \text { Harvestable } \\ \text { Leaves/Plant } \\ (\mathrm{gm})\end{array} & \begin{array}{l}\text { Average } \\ \text { Single Leaf } \\ (\mathrm{gm})\end{array} & \begin{array}{l}\text { Total Leaf } \\ \text { Yeild/Hectare } \\ (\mathrm{kg})\end{array}\end{array}$

f Harvesting

v 2002

i1 2003

ly 2003

$257.26 \mathrm{a}$

$169.17 \mathrm{a} \quad 3.23 \mathrm{~b}$

$51.52 \mathrm{~b}$

$4.65 \mathrm{a}$

$233.67 \mathrm{~b}$

$122.37 \mathrm{~b} \quad 5.44 \mathrm{~b}$

$52.22 \mathrm{a}$

$2.38 \mathrm{~b}$

$232.52 \mathrm{~b}$

$146.87 \mathrm{ab} \quad 10.15 \mathrm{a}$

86.74 a

$245.26 \mathrm{~b}$

$1.89 \mathrm{~b}$

systems

Practice

ional I

$183.54 \mathrm{c}$

$118.22 \mathrm{c} \quad 5.15 \mathrm{~d}$

$110 \mathrm{c}$

366.19 a

$361.14 \mathrm{a}$

ional II

$232.18 \mathrm{~b}$

$142.01 \mathrm{~b} \quad 6.40 \mathrm{bc}$

$133.25 \mathrm{ab}$

$203.52 \mathrm{e}$

$2.39 \mathrm{e}$

$312.29 \mathrm{~cd} \quad 2.82 \mathrm{c}$

$7928 \mathrm{~cd}$

285.19 a

$147.07 \mathrm{a}$

$413.11 \mathrm{~b}$

$3.52 \mathrm{a}$

$12367 \mathrm{~b}$

$292.30 \mathrm{a}$

$151.76 \mathrm{a}$

$474.61 \mathrm{a}$

$3.65 \mathrm{a}$

16329 a

268.99 a

$170.24 \mathrm{a} \quad 7.81 \mathrm{a}$

$135.75 \mathrm{ab}$

$358.41 \mathrm{bc}$

18860 a

$234.60 \mathrm{~b}$

$142.55 \mathrm{~b}$

$125.46 \mathrm{bc}$

$288.54 \mathrm{~d}$

$3.16 \mathrm{~b}$

$10489 \mathrm{bc}$

$\mathrm{Fa}$

$120.03 \mathrm{c} \quad 5.24 \mathrm{~d}$

$107.14 \mathrm{c}$

$218.91 \mathrm{e}$

$2.74 \mathrm{~cd}$

$8478 \mathrm{~cd}$

Farming II $191.18 \mathrm{c}$

$2.52 \mathrm{de}$

$6413 \mathrm{~d}$

in for each factor (seasons and agroecosystems) means followed by the same letter are not significantly t $5 \%$ levelDMRT

Description

ractice = Row system $+100-50-50 \mathrm{~kg} \mathrm{NPK} / \mathrm{ha}$

nal I $=$ Row system $+200-50-50 \mathrm{~kg} \mathrm{NPK} / \mathrm{ha}$

onal II $=$ Pit system $+200-50-50 \mathrm{~kg} \mathrm{NPK} / \mathrm{ha}$

$=$ Pit system $+100-50-50 \mathrm{~kg} \mathrm{NPK} / \mathrm{ha}+10 \mathrm{t}$ manure + green manure + mulch

$=$ Pit system $+50-50-50 \mathrm{~kg} \mathrm{NPK} \mathrm{ha}^{-1}+10 \mathrm{t}$ manure + green manure + green leaf manure + mulch

arming I $=$ Pit system +10 t manure + green manure + green leaf manure + mulch

arming II $=$ Pit system + green manure + green leaf manure + mulch 
ffect of season and agroecosystems on the growth, yield, and quality of mulberry in the second year of establishment.

\begin{tabular}{lllllll}
$\begin{array}{l}\text { Plant } \\
\text { Height } \\
(\mathrm{cm})\end{array}$ & $\begin{array}{l}\text { Length of } \\
\text { Shoots } \\
(\mathrm{cm})\end{array}$ & $\begin{array}{l}\text { Number of } \\
\text { Branches/Plant }\end{array}$ & $\begin{array}{l}\text { Number of } \\
\text { Leaves/Plant }\end{array}$ & $\begin{array}{l}\text { Weight of } \\
\text { Harvestable } \\
\text { Leaves/Plant } \\
(\mathrm{gm})\end{array}$ & $\begin{array}{l}\text { Average } \\
\text { Single Leaf } \\
(\mathrm{gm})\end{array}$ & $\begin{array}{l}\text { Total Leaf } \\
\text { Yield/Hectare } \\
(\mathrm{kg})\end{array}$ \\
\hline
\end{tabular}

\begin{tabular}{|c|c|c|c|c|c|c|c|}
\hline 2003 & $196.39 \mathrm{a}$ & $129.56 \mathrm{a}$ & $6.39 \mathrm{c}$ & $125.05 \mathrm{ab}$ & $456.80 \mathrm{a}$ & $3.63 \mathrm{a}$ & \\
\hline 2003 & $184.61 \mathrm{a}$ & $94.28 \mathrm{~b}$ & $8.07 \mathrm{~b}$ & $104.64 \mathrm{c}$ & $291.41 b c$ & $2.12 \mathrm{~b}$ & \\
\hline h 2004 & $169.02 \mathrm{~b}$ & $71.36 \mathrm{c}$ & $5.85 \mathrm{c}$ & $117.07 \mathrm{bc}$ & $212.29 \mathrm{c}$ & $1.82 \mathrm{~b}$ & \\
\hline ne 2004 & $182.85 \mathrm{ab}$ & $85.87 \mathrm{~b}$ & $5.85 \mathrm{c}$ & $135.96 \mathrm{a}$ & $291.41 \mathrm{~b}$ & $2.16 \mathrm{~b}$ & \\
\hline \multicolumn{8}{|l|}{ systems } \\
\hline Practice & $160.71 \mathrm{~d}$ & $71.90 \mathrm{e}$ & $6.34 \mathrm{ef}$ & $109.29 \mathrm{c}$ & $229.25 \mathrm{~d}$ & $2.05 \mathrm{~cd}$ & $11610.60 \mathrm{de}$ \\
\hline onal I & $180.85 \mathrm{bc}$ & $98.85 \mathrm{~b}$ & $7.27 \mathrm{~d}$ & $115.47 \mathrm{bc}$ & $298.93 \mathrm{c}$ & $2.48 \mathrm{~b}$ & $15372.20 \mathrm{c}$ \\
\hline onal II & $210.60 \mathrm{a}$ & $115.24 \mathrm{a}$ & $8.89 \mathrm{~b}$ & $119.91 \mathrm{bc}$ & $354.97 \mathrm{~b}$ & $2.82 \mathrm{a}$ & $18367.00 \mathrm{~b}$ \\
\hline & $208.50 \mathrm{a}$ & $116.33 \mathrm{a}$ & $9.55 \mathrm{a}$ & $138.39 \mathrm{a}$ & $413.68 \mathrm{a}$ & $2.91 \mathrm{a}$ & $21536.90 \mathrm{a}$ \\
\hline & $186.30 \mathrm{~b}$ & $98.19 \mathrm{~b}$ & $7.87 \mathrm{c}$ & $127.24 \mathrm{ab}$ & $351.87 \mathrm{~b}$ & $2.62 \mathrm{~b}$ & $13566.30 \mathrm{c}$ \\
\hline Farming I & $176.23 \mathrm{c}$ & $87.59 \mathrm{c}$ & $6.82 \mathrm{de}$ & $120.50 \mathrm{bc}$ & $288 \mathrm{c}$ & $2.18 \mathrm{c}$ & $11073.00 \mathrm{e}$ \\
\hline Farming II & $159.34 \mathrm{~d}$ & 78.78 & $5.84 \mathrm{f}$ & $111.97 \mathrm{c}$ & $213.80 \mathrm{~d}$ & $1.95 \mathrm{~d}$ & $8106.10 \mathrm{f}$ \\
\hline
\end{tabular}

in for each factor (seasons and agroecosystems) means followed by the same letter are not significantly t $5 \%$ levelDMRT

Description

ractice = Row system $+100-50-50 \mathrm{~kg} \mathrm{NPK} / \mathrm{ha}$

nal I $=$ Row system $+200-50-50 \mathrm{~kg} \mathrm{NPK} / \mathrm{ha}$

onal II $=$ Pit system $+200-50-50 \mathrm{~kg} \mathrm{NPK} / \mathrm{ha}$

$=$ Pit system $+100-50-50 \mathrm{~kg} \mathrm{NPK} / \mathrm{ha}+10 \mathrm{t}$ manure + green manure + mulch

$=$ Pit system $+50-50-50 \mathrm{~kg} \mathrm{NPK} \mathrm{ha}{ }^{-1}+10 \mathrm{t}$ manure + green manure + green leaf manure + mulch

arming I $=$ Pit system +10 t manure + green manure + green leaf manure + mulch

arming II $=$ Pit system + green manure + green leaf manure + mulch 
Table 5. Estimates of $\mathrm{N}$ applied from different sources on its first year of establishment in Sta. Maria Ilocos Sur.

\begin{tabular}{llll}
\hline Treatment & Inorganic Source & $\begin{array}{l}\text { Total Biomass } \\
\text { Applied Dry } \\
\text { Matter Yield } \\
\mathrm{kg} / \mathrm{ha}\end{array}$ & $\begin{array}{l}\text { Total N } \\
\text { Applied }\end{array}$ \\
$\mathrm{kg} / \mathrm{ha}$ \\
\hline First Year & & & \\
Existing Practice & 100 & 4600.00 & 100.00 \\
Conventional I & 200 & 4600.00 & 430.00 \\
Conventional II & 200 & 6470.68 & 430.00 \\
LEISA I & 100 & 8937.97 & 448.10 \\
LEISA II & 50 & 8697.23 & 365.28 \\
Organic Farming I & 0 & 5148.80 & 178.80 \\
Organic Farming II & 0 & & \\
\hline
\end{tabular}

Treatment Description

Existing Practice $=$ Row system $+100-50-50 \mathrm{~kg} \mathrm{NPK} / \mathrm{ha}$

Conventional I = Row system $+200-50-50 \mathrm{~kg} \mathrm{NPK} / \mathrm{ha}$

Conventional II $=$ Pit system $+200-50-50 \mathrm{~kg} \mathrm{NPK} / \mathrm{ha}$

LEISA I $=$ Pit system $+100-50-50 \mathrm{~kg} \mathrm{NPK} / \mathrm{ha}+10 \mathrm{t}$ manure + green manure +

mulch

LEISA II = Pit system $+50-50-50 \mathrm{~kg} \mathrm{NPK} \mathrm{ha}^{-1}+10 \mathrm{t}$ manure + green manure + green leaf manure + mulch

Organic Farming $\mathrm{I}=$ Pit system $+10 \mathrm{t}$ manure + green manure + green leaf manure + mulch

Organic Farming II $=$ Pit system + green manure + green leaf manure + mulch

Applying chemical fertilizer alone as in Existing Practice proved the least effective. With the addition of organic nutrient sources as in animal and green and green leaf manure crops, the mulberry leaf yield significantly improved in pit planting (LEISA1) over that of Existing Practice. It led to more leaf biomass especially during summer or drier months. Pit planting helps in deep rooting, quick establishment, and luxuriant growth of mulberry plants. With a pit, the application of organic fertilizers deep in the root zone improved soil water retention making it moist throughout the growing season and allowing water and nutrients uptake (FAO, 1990). The application of organic manure with micronutrients combined with or without inorganic fertilizer helped in increasing the availability of nutrients and crop yield and in sustaining and restoring soil fertility (Singh et al., 2011). Green manures can be easily grown in the farms. Seeds can be mass propagated and stored for the next cropping seasons. Green manures are capable of increasing soil fertility (Thorup-Kristensen et al., 2003). Other products such as food, 
income, fuel, stakes for climbing fodder, and useful products are highly preferred. In Region 1, Philippines, the use of Vigna species (mungbean and cowpeas), and pigeon pea is common. Should these crops be integrated in the mulberry farms as green manures, they would add to the fertility in the soil while still functioning as food crops.

Production practices such as crop rotation, green manuring, composting and mulching, crop diversity and recycling animal manure, use of organic matter as the only fertilizer, pests and disease control involving cultural practices and organic chemicals from herbs (Jitsanguan, 2001) altogether promote and enhance agroecosystems health, biological cycles, and biological activity (Fließbach, et al., 2007; Fließbach and Mäder, 2000). Furthermore, these production practices reduce the use of direct and indirect fossil fuel based energy (Pimentel et al., 2005) and the associated greenhouse gas emission (Smith et al., 2007; Niggli et al., 2009). These are the features of organic farming (Badgley et al., 2007; Pimentel et al., 1995; Reganold et al., 1987) which restores soil health and the long term soil productivity that could be done by sericulture farmers; hence, providing more benefits (human food, animal feed, fuel, shade and income (IFAD, IDRC etal., 2001).

Pit planting, application of adequate amounts of $\mathrm{N}$ both by inorganic and organic manures, and green manuring led to higher performances of LEISA I and Conventional II. Nitrogen, Phosphorus and Potassium are vital for increased mulberry leaf production. Nitrogen is involved in the building up of plant tissues and protein synthesis and thus determines over-all growth (Cosico, 2005). Leaf yield was reduced by $10 \%$ when $\mathrm{N}, 6 \%$ when $\mathrm{P}_{2} 0_{5}$, and $12 \%$ when $\mathrm{K}_{2} 0$ were not applied. Insufficiency of $\mathrm{N}$ leads to reduced proteins and water contents of leaves but with adequate $\mathrm{N}$, mulberry has more succulent leaves and improved feeding value (FAO, 1990). P is a constituent of cell nucleus and essential in cell division. $K$ influences the development of woody parts of the stem essential for photosynthesis and translocation of starch for sustained yield of quality leaves. $\mathrm{P}$ and $\mathrm{K}$ aid in the efficient utilization of $\mathrm{N}$ increasing the quality of leaves (FAO, 1987).

Yields depend on variety, location, (monthly temperature, solar radiation and rainfall) plant density, fertilizer application, and harvesting technique (Sanchez, 2000). Some plant characters were influenced by season in the different agroecosystems. They were plant height, length of shoots, and number of branches and average single leaf weight (Table 6). Plants grown in LEISA II, LEISA I, and Conventional II from June-November 
were significantly taller than the rest of treatment combinations. Longer shoots were also observed in Conventional II and LEISA I of the same month. The number of leaves in LEISA I from May to July was significantly the highest. Heaviest average single leaf was also recorded in LEISA I from June to November. The least performers were observed in Organic Farming II and Existing Practice regardless of months harvested (Table 6).

In the second year, plant characters affected by seasons in the six agroecosystems were length of shoots, number of branches, weight of harvestable leaves, and average single leaf weight were observed (Table 7). Mulberry plants were taller in Conventional II and LEISA I from June to October and October to December and Conventional II from April to July. Longest shoots were significantly recorded in LEISA I from July to October while the most branches were recorded in the same systems from January to March. Likewise, LEISA I from January to March significantly recorded the heaviest harvestable leaves and average single leaf. Regardless of seasons, plants in Organic farming II and the Existing practice had shorter plants and shoot lengths, less branches and number of leaves, and lighter harvestable leaves and average single leaf compared with the other treatment combinations (Table 7).

The use of organic farming techniques can be a good alternative to conventional sericulture farming. When farms are initially converted to organic methods, yields may fall significantly because it takes time for the biological processes in organic systems to become established. Nutrient deficiencies may sometimes occur (Alvarez et al., 1999). This was observed during the first year growth of mulberry in the organic treatments (Organic farming I and II). However, this lower yield in the early stage should not be taken as an indicator to actual yields. Established organic farms give significantly higher yields than conventional systems in a longer span of time (Alvarez et al., 1999). Silk wastes are good source of organic materials and they could be composted in 4 months (Bogesha et al., 2005). 
Table 6. Interaction effects between season x agroecosystems on the growth and yield of mulberry during its first years of establishment in Sta. Maria, Ilocos Sur.

\begin{tabular}{|c|c|c|c|c|c|c|}
\hline Factors & $\begin{array}{l}\text { Plant } \\
\text { Height } \\
(\mathrm{cm})\end{array}$ & $\begin{array}{l}\text { Length of } \\
\text { Shoots } \\
(\mathrm{cm})\end{array}$ & $\begin{array}{l}\text { Number } \\
\text { of } \\
\text { Branches } \\
\text { /Plant } \\
\end{array}$ & $\begin{array}{l}\text { Number } \\
\text { of Leaves/ } \\
\text { Plant (g) }\end{array}$ & $\begin{array}{l}\text { Weight of } \\
\text { Harvestable } \\
\text { Leaves/ } \\
\text { Plant }\end{array}$ & $\begin{array}{l}\text { Average } \\
\text { Single Leaf } \\
\text { Weight (g) }\end{array}$ \\
\hline \multicolumn{7}{|l|}{ June to November 2002} \\
\hline Existing Practice & $215.01 \mathrm{~g}-\mathrm{i}$ & $129.04 \mathrm{~d}-\mathrm{f}$ & $2.80 \mathrm{i}$ & 44.94 & 180.80 & $4.02 \mathrm{c}$ \\
\hline Conventional I & $219.59 \mathrm{f}-\mathrm{i}$ & $162.85 \mathrm{c}-\mathrm{d}$ & $3.53 \mathrm{~g}-\mathrm{i}$ & 52.21 & 207.92 & $4.23 \mathrm{c}$ \\
\hline Conventional II & $331.77 \mathrm{a}-\mathrm{b}$ & $206.88 \mathrm{a}-\mathrm{b}$ & $3.51 \mathrm{~g}-\mathrm{i}$ & 50.48 & 283.34 & $5.58 \mathrm{c}$ \\
\hline LEISA I & $325.30 \mathrm{a}$ & $213.46 \mathrm{a}$ & $3.65 \mathrm{f}-\mathrm{i}$ & 54.49 & 349.41 & $5.57 \mathrm{a}$ \\
\hline LEISA II & 290.37 a-c & $185.97 \mathrm{a}-\mathrm{c}$ & $3.37 \mathrm{~g}-\mathrm{i}$ & 57.85 & 291.08 & $4.97 \mathrm{~b}$ \\
\hline Organic Farming I & $259.23 \mathrm{c}-\mathrm{g}$ & $160.88 \mathrm{c}-\mathrm{d}$ & $3.03 \mathrm{~g}-\mathrm{i}$ & 56.33 & 236.89 & $4.23 \mathrm{c}$ \\
\hline $\begin{array}{l}\text { Organic Farming II } \\
\text { January to April } 2003\end{array}$ & $183.60 \mathrm{i}-\mathrm{j}$ & $125.14 \mathrm{~d}-\mathrm{f}$ & $2.82 \mathrm{~h}-\mathrm{i}$ & 42.25 & 167.32 & $3.96 \mathrm{c}$ \\
\hline Existing Practice & $189.50 \mathrm{i}-\mathrm{j}$ & $88.70 \mathrm{f}$ & $4.57 \mathrm{e}-\mathrm{i}$ & 144.63 & 236.67 & $1.77 \mathrm{~g}-\mathrm{i}$ \\
\hline Conventional I & $234.67 \mathrm{~d}-\mathrm{h}$ & $125.53 \mathrm{~d}-\mathrm{f}$ & $5.93 \mathrm{e}$ & 151.65 & 349.67 & $2.30 \mathrm{f}-\mathrm{g}$ \\
\hline Conventional II & $263.40 \mathrm{c}-\mathrm{f}$ & $147.64 \mathrm{c}-\mathrm{d}$ & $6.07 \mathrm{e}$ & 162.30 & 480.00 & $2.91 \mathrm{~d}-\mathrm{e}$ \\
\hline LEISA I & $262.93 \mathrm{c}-\mathrm{f}$ & $136.22 \mathrm{c}-\mathrm{e}$ & $6.40 \mathrm{~d}-\mathrm{e}$ & 184.92 & 576.67 & $3.10 \mathrm{~d}$ \\
\hline LEISA II & $247.47 \mathrm{c}-\mathrm{g}$ & $133.54 \mathrm{~d}-\mathrm{e}$ & 5.40 e-f & 153.60 & 375.67 & $2.42 \mathrm{e}-\mathrm{f}$ \\
\hline Organic Farming I & $224.07 \mathrm{f}-\mathrm{i}$ & $127.56 \mathrm{~d}-\mathrm{f}$ & $4.97 \mathrm{e}-\mathrm{i}$ & 143.57 & 313.67 & $2.19 \mathrm{f}-\mathrm{h}$ \\
\hline $\begin{array}{l}\text { Organic Farming II } \\
\text { May to July } 2003\end{array}$ & $205.63 \mathrm{~h}-\mathrm{i}$ & 97.47 e-f & $4.77 \mathrm{e}-\mathrm{h}$ & 124.96 & 231.00 & $1.93 \mathrm{f}-\mathrm{i}$ \\
\hline Existing Practice & $146.10 \mathrm{i}-\mathrm{i}$ & $136.91 \mathrm{c}-\mathrm{e}$ & $8.07 \mathrm{c}-\mathrm{d}$ & 140.44 & 193.08 & $1.37 \mathrm{i}$ \\
\hline Conventional I & $242.30 \mathrm{~d}-\mathrm{h}$ & $142.56 \mathrm{c}-\mathrm{d}$ & $9.86 \mathrm{~b}-\mathrm{c}$ & 195.97 & 379.29 & $1.93 \mathrm{f}-\mathrm{i}$ \\
\hline Conventional II & $278.41 \mathrm{~b}-\mathrm{d}$ & $156.14 \mathrm{c}-\mathrm{d}$ & $11.19 \mathrm{~b}$ & 228.43 & 475.75 & $2.07 \mathrm{f}-\mathrm{h}$ \\
\hline LEISA I & $288.66 \mathrm{a}-\mathrm{c}$ & $161.04 \mathrm{~b}-\mathrm{d}$ & $13.39 \mathrm{a}$ & 215.87 & 497.75 & $2.27 \mathrm{f}-\mathrm{g}$ \\
\hline LEISA II & $269.22 \mathrm{c}-\mathrm{e}$ & $154.76 \mathrm{c}-\mathrm{d}$ & $11.09 \mathrm{~b}$ & 195.81 & 408.48 & $2.07 \mathrm{f}-\mathrm{h}$ \\
\hline Organic Farming I & $226.72 \mathrm{i}-\mathrm{j}$ & $139.20 \mathrm{c}-\mathrm{d}$ & $9.28 \mathrm{c}$ & 176.49 & 315.06 & $1.80 \mathrm{~g}-\mathrm{i}$ \\
\hline Organic Farming II & $184.30 \mathrm{i}-\mathrm{j}$ & $137.49 \mathrm{c}-\mathrm{e}$ & $8.14 \mathrm{c}-\mathrm{d}$ & 154.20 & 258.40 & $1.69 \mathrm{~h}-\mathrm{i}$ \\
\hline
\end{tabular}

In a column for each factor (seasons and agro-ecosystem), means followed by the same letter are not significantly different from each other at $5 \%$ level DMRT.

Treatment Description

Existing Practice $=$ Row system $+100-50-50 \mathrm{~kg} \mathrm{NPK} / \mathrm{ha}$

Conventional I $\quad=$ Row system $+200-50-50 \mathrm{~kg} \mathrm{NPK} / \mathrm{ha}$

Conventional II $=$ Pit system $+200-50-50 \mathrm{~kg} \mathrm{NPK} / \mathrm{ha}$

LEISA I $\quad=$ Pit system $+100-50-50 \mathrm{~kg} \mathrm{NPK} / \mathrm{ha}+10 \mathrm{t}$ manure + green manure +

mulch

LEISA II $\quad=$ Pit system $+50-50-50 \mathrm{~kg} \mathrm{NPK} \mathrm{ha}^{-1}+10 \mathrm{t}$ manure + green manure + green leaf manure + mulch

Organic Farming I $=$ Pit system $+10 \mathrm{t}$ manure + green manure + green leaf manure + mulch

Organic Farming II $=$ Pit system + green manure + green leaf manure + mulch 
Table 7. Interaction effects of season $\mathrm{x}$ agro-ecosystems on the growth and yield of mulberry during its second year establishment in Sta. Maria, Ilocos Sur.

\begin{tabular}{|c|c|c|c|c|c|c|}
\hline Factors & $\begin{array}{l}\text { Plant Height } \\
(\mathrm{cm})\end{array}$ & $\begin{array}{l}\text { Length of } \\
\text { Shoots } \\
(\mathrm{cm})\end{array}$ & $\begin{array}{l}\text { Number } \\
\text { of } \\
\text { Branches/ } \\
\text { Plant }\end{array}$ & $\begin{array}{l}\text { Number of } \\
\text { Leaves/Plant } \\
(\mathrm{g})\end{array}$ & $\begin{array}{l}\text { Weight of } \\
\text { Harvestable } \\
\text { Leaves/Plant }\end{array}$ & $\begin{array}{l}\text { Average } \\
\text { Single Leaf } \\
\text { Weight }(g)\end{array}$ \\
\hline \multicolumn{7}{|l|}{ July to October 2003} \\
\hline Existing Practice & $169.40 \mathrm{~g}-1$ & $94.81 \mathrm{~h}-\mathrm{i}$ & $5.221-\mathrm{n}$ & 114.08 & $305.99 \mathrm{e}-\mathrm{h}$ & $2.72 \mathrm{e}-\mathrm{j}$ \\
\hline Conventional I & $195.09 \mathrm{c}-\mathrm{e}$ & $140.99 \mathrm{c}$ & $6.37 \mathrm{i}-1$ & 124.40 & $458.75 \mathrm{c}-\mathrm{d}$ & $3.71 \mathrm{c}-\mathrm{d}$ \\
\hline Conventional II & $216.60 a-b$ & $154.33 \mathrm{~b}$ & $7.87 \mathrm{e}-\mathrm{h}$ & 123.96 & $504.53 \mathrm{~b}-\mathrm{c}$ & $4.06 \mathrm{~b}-\mathrm{c}$ \\
\hline LEISA I & 229.97 a & $163.40 \mathrm{a}$ & $8.00 \mathrm{~d}-\mathrm{g}$ & 142.86 & $637.38 \mathrm{a}$ & $4.44 \mathrm{a}$ \\
\hline LEISA II & $204.40 \mathrm{~b}-\mathrm{c}$ & $128.13 \mathrm{~d}$ & $6.97 \mathrm{f}-\mathrm{j}$ & 143.95 & $556.73 \mathrm{~b}$ & $3.87 \mathrm{~b}$ \\
\hline Organic Farming I & $189.60 \mathrm{c}-\mathrm{f}$ & $117.72 \mathrm{e}-\mathrm{f}$ & $5.70 \mathrm{k}-\mathrm{n}$ & 131.81 & $447.35 \mathrm{c}-\mathrm{d}$ & $3.43 \mathrm{c}-\mathrm{d}$ \\
\hline $\begin{array}{l}\text { Organic Farming II } \\
\text { October - December } 2003\end{array}$ & $169.70 \mathrm{~g}-\mathrm{k}$ & $107.59 \mathrm{f}-\mathrm{h}$ & $4.63 n$ & 94.33 & $290.52 \mathrm{e}-\mathrm{j}$ & $3.16 \mathrm{e}-\mathrm{i}$ \\
\hline Existing Practice & 148.271 & $68.571-n$ & $6.63 \mathrm{~g}-1$ & 93.44 & 203.73 i-1 & $1.91 \mathrm{i}-1$ \\
\hline Conventional I & $183.21 \mathrm{e}-\mathrm{g}$ & $94.78 \mathrm{~g}-\mathrm{h}$ & $7.28 \mathrm{f}-\mathrm{j}$ & 100.54 & $245.11 \mathrm{f}-\mathrm{k}$ & $2.10 \mathrm{f}-\mathrm{k}$ \\
\hline Conventional II & $221.74 \mathrm{a}$ & $111.62 \mathrm{e}-\mathrm{f}$ & $10.04 \mathrm{~b}-\mathrm{c}$ & 109.94 & $333.47 \mathrm{e}-\mathrm{g}$ & $2.47 \mathrm{e}-\mathrm{g}$ \\
\hline LEISA I & $215.88 \mathrm{a}-\mathrm{b}$ & $120.63 \mathrm{~d}-\mathrm{e}$ & $10.90 \mathrm{~b}$ & 115.59 & $340.64 \mathrm{e}-\mathrm{f}$ & $2.55 \mathrm{e}-\mathrm{f}$ \\
\hline LEISA II & $188.80 \mathrm{~d}-\mathrm{f}$ & $103.17 \mathrm{f}-\mathrm{h}$ & $8.31 \mathrm{~d}-\mathrm{f}$ & 107.19 & $280.08 \mathrm{f}-\mathrm{k}$ & $2.21 \mathrm{f}-\mathrm{k}$ \\
\hline Organic Farming I & $174.47 \mathrm{f}-\mathrm{j}$ & $85.44 \mathrm{i}-\mathrm{j}$ & $7.20 \mathrm{f}-\mathrm{j}$ & 101.90 & $278.24 \mathrm{f}-\mathrm{k}$ & $1.86 \mathrm{f}-\mathrm{k}$ \\
\hline $\begin{array}{l}\text { Organic Farming II } \\
\text { January to March } 2004\end{array}$ & $159.87 \mathrm{j}-\mathrm{i}$ & $75.68 \mathrm{j}-1$ & $6.17 \mathrm{j}-\mathrm{m}$ & 103.87 & $196.77 \mathrm{j}-1$ & $1.71 \mathrm{j}-1$ \\
\hline Existing Practice & $167.91 \mathrm{~h}-\mathrm{j}$ & $57.54 \mathrm{k}-\mathrm{m}$ & $7.81 \mathrm{e}-\mathrm{h}$ & 93.66 & $171.61 \mathrm{j}-1$ & 1.831 \\
\hline Conventional I & $168.32 \mathrm{~g}-\mathrm{k}$ & $70.67 \mathrm{~m}-\mathrm{o}$ & $9.31 \mathrm{c}-\mathrm{d}$ & 167.02 & 200.571 & $1.89 \mathrm{j}-1$ \\
\hline Conventional II & $182.05 \mathrm{e}-\mathrm{h}$ & $82.36 \mathrm{j}-\mathrm{k}$ & $11.38 \mathrm{~b}$ & 113.93 & $240.90 \mathrm{~g}-1$ & $2.12 \mathrm{~g}-\mathrm{k}$ \\
\hline LEISA I & $187.62 \mathrm{~d}-\mathrm{f}$ & $83.10 \mathrm{j}$ & $12.76 \mathrm{a}$ & 149.75 & $297.45 \mathrm{e}-\mathrm{i}$ & $1.98 \mathrm{e}-\mathrm{i}$ \\
\hline LEISA II & $162.57 \mathrm{j}-\mathrm{k}$ & $73.12 \mathrm{j}-1$ & $10.14 \mathrm{~b}-\mathrm{c}$ & 109.80 & $228.65 \mathrm{i}-\mathrm{m}$ & $2.08 \mathrm{~h}-1$ \\
\hline Organic Farming I & $158.24 \mathrm{k}-1$ & $65.88 \mathrm{l}-\mathrm{o}$ & $8.96 \mathrm{c}-\mathrm{e}$ & 125.44 & $185.60 \mathrm{k}-\mathrm{l}$ & $1.48 \mathrm{k}-\mathrm{l}$ \\
\hline $\begin{array}{l}\text { Organic Farming II } \\
\text { April to July } 2004\end{array}$ & $156.43 \mathrm{k}-1$ & $60.16 \mathrm{n}-\mathrm{o}$ & $7.77 \mathrm{e}-\mathrm{i}$ & 119.89 & $160.90 \mathrm{n}$ & 1.341 \\
\hline Existing Practice & $157.25 \mathrm{k}-1$ & 66.69 o & $5.72 \mathrm{k}-\mathrm{n}$ & 135.96 & $235.68 \mathrm{~h}-1$ & $1.73 \mathrm{~h}-1$ \\
\hline Conventional I & $176.76 \mathrm{f}-\mathrm{i}$ & $82.30 \mathrm{j}-1$ & $6.13 \mathrm{j}-\mathrm{m}$ & 130.26 & $291.30 \mathrm{e}-\mathrm{i}$ & $2.23 \mathrm{e}-\mathrm{i}$ \\
\hline Conventional II & $222.00 \mathrm{a}$ & $112.63 \mathrm{f}-\mathrm{g}$ & $6.29 \mathrm{j}-1$ & 131.81 & $344.25 \mathrm{e}-\mathrm{f}$ & $2.62 \mathrm{e}-\mathrm{f}$ \\
\hline LEISA I & $200.52 \mathrm{c}-\mathrm{d}$ & $98.19 \mathrm{~h}$ & $6.52 \mathrm{~h}-1$ & 145.36 & $379.28 \mathrm{~d}-\mathrm{e}$ & $2.66 \mathrm{~d}-\mathrm{e}$ \\
\hline LEISA II & $189.42 \mathrm{c}-\mathrm{f}$ & $88.36 \mathrm{j}-\mathrm{k}$ & $6.05 \mathrm{k}-\mathrm{n}$ & 148.01 & $341.6 \mathrm{e}-\mathrm{f}$ & $2.33 \mathrm{e}-\mathrm{f}$ \\
\hline Organic Farming I & $182.61 \mathrm{e}-\mathrm{h}$ & $81.25 \mathrm{k}-\mathrm{m}$ & $5.431-n$ & 122.87 & $240.52 \mathrm{~g}-1$ & $1.97 \mathrm{e}-\mathrm{k}$ \\
\hline Organic Farming II & 151.371 & $71.70 \mathrm{~m}-\mathrm{o}$ & $4.87 \mathrm{~m}-\mathrm{n}$ & 131.57 & $206.91 \mathrm{i}-1$ & $1.58 \mathrm{i}-1$ \\
\hline
\end{tabular}

In a column for each factor (seasons and agroecosystems), means followed by the same letter are not significantly different from each other at $5 \%$ level DMRT. 
Improving Mulberry Leaf Yield and Quality to Increase Silkworm Productivity

\section{Protein Content of Mulberry at Different Ages After Pruning}

Protein contents decreased as the mulberry leaves matured. At 50 days after pruning, protein contents of the shoots ranged from $26 \%$ to $31 \%$; at 1 $10^{\text {th }}$ positions (for young-age feeding), from 21 to $25 \%$ while lower leaves ranged from 18 to $22 \%$ (Figure 4). Regardless of leaf position, Conventional II had the highest protein content of $25 \%$, followed by LEISA II, Conventional I, and LEISA I, with 25, 24, and 24\%, respectively. Organic Farming II had 23\% and Existing Practice, 23\%. Higher protein in Conventional I and II could be a consequence of higher $\mathrm{N}$ applied. With more $\mathrm{N}$, crude protein increased while sugar, phosphoric acid, potash and lime increased. $\mathrm{N}$ influenced total yield of mulberry leaves while $\mathrm{P}$ and $\mathrm{K}$ aided in utilization of $\mathrm{N}$, thereby improving the quality and quantity of leaves (Central Silk Board, 1987).

At 60 days after pruning, protein contents of shoots were highest in Organic Farming I, Conventional I and II and LEISA II, lowest in LEISA I, Organic Farming II and Existing Practice (Figure 5). At $1^{\text {st }}-5^{\text {th }}$ leaf positions, contents were highest in Conventional I, LEISA II, and Conventional II. At $6^{\text {th }}-10^{\text {th }}$ leaf position, Existing Practice had the highest protein content, the lowest in Organic Farming II. At $11-15^{\text {th }}$ leaf position, protein contents were highest in LEISA I and lowest in Organic Farming II. At 16-20 $0^{\text {th }}$ leaf position, protein content was highest in LEISA II and lowest in Existing Practice. At 21-25th leaf position, protein content was highest in Conventional I and the lowest was observed in LEISA II. It could be noted that protein contents of mulberry leaves decreased with the maturity of leaves.

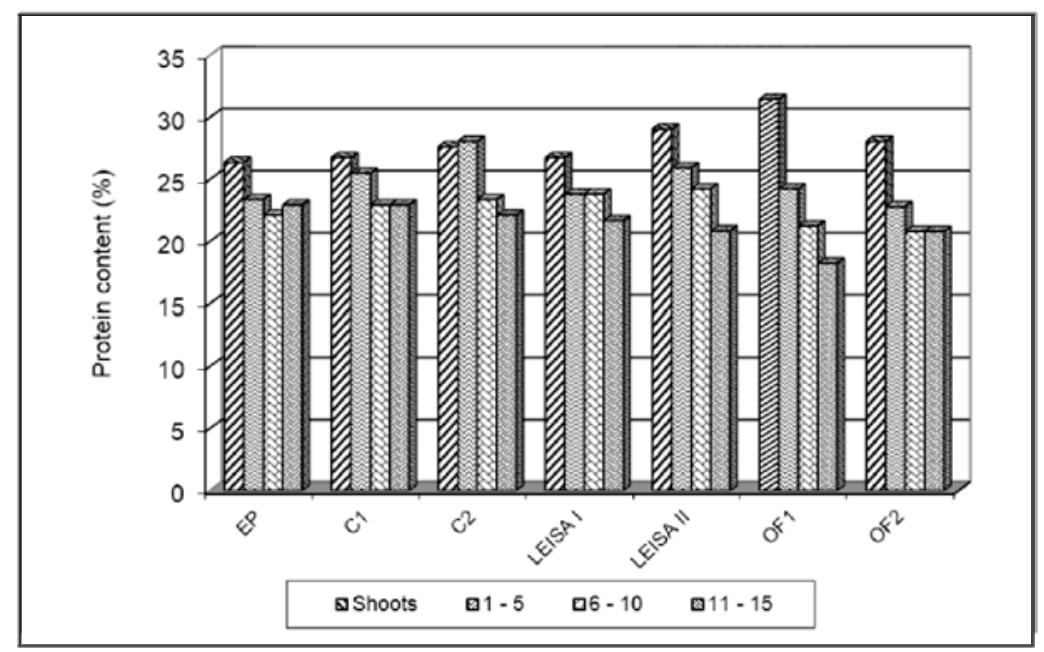

Figure 4. Protein content of mulberry leaves at different leaf positions, (50DAP) in Sta. Maria, Ilocos Sur. 


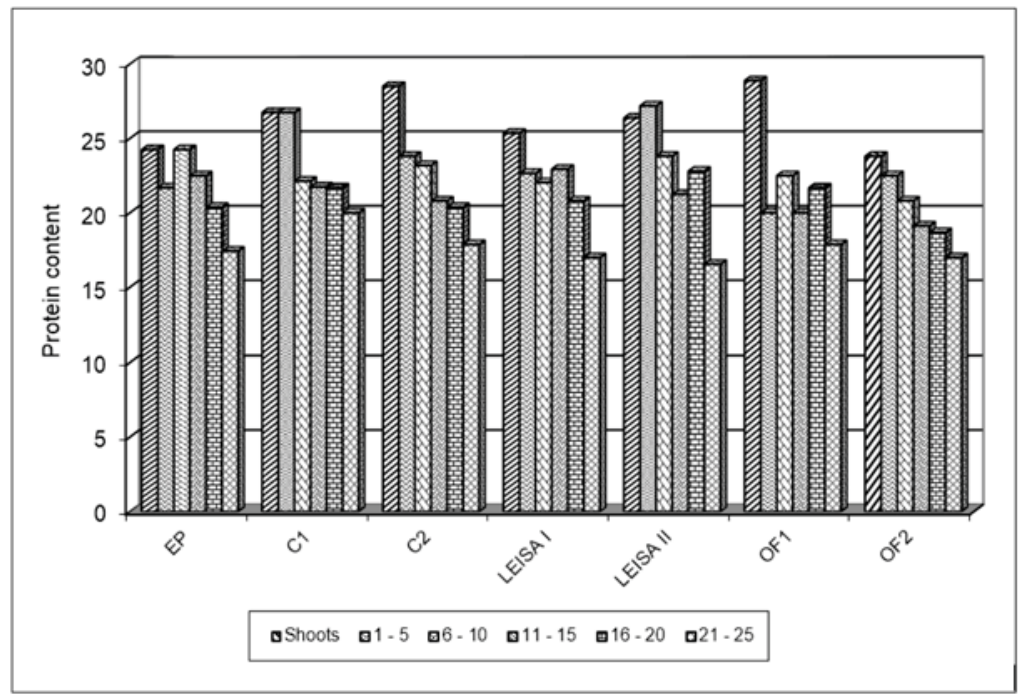

Figure 5. Protein content of mulberry leaves at different leaf positions (60DAP) in Sta. Maria, Ilocos Sur.

On the average, Conventional I, Conventional II, LEISA II and Organic Farming I had higher protein contents ranging from 22.15 to 23.24\%. Existing Practice, LEISA I and Organic Farming II had lower protein contents ranging from 20.32 to 21.75 percent. However, these leaves had acceptable protein levels suited for late-age rearing.

\section{Moisture Content of Mulberry Leaves at Different Times of Harvesting and Leaf Positions During Summer}

At 45 days after pruning (DAP), moisture contents of leaves ranged from 79.77 to $87.45 \%$ depending on the agroecosystems. There were no significant differences in moisture contents of the different treatments except for Organic Farming II. The trend was that water declined as the leaves matured (Fig.6). On the $65^{\text {th }}$ day after pruning, no variations on the moisture contents of the shoots were observed but at the $1-5^{\text {th }}$ leaf positions. LEISA I and Conventional treatments had similar moisture contents with Existing Practice while of the $6-9^{\text {th }}$ position, LEISA I and Conventional treatments had higher moisture contents than the other treatments. At lower levels, no differences were observed at $10-15^{\text {th }}$ leaf positions but at the $16-20^{\text {th }}$ position the Conventional I and II and the LEISA I \& II had more moisture contents than the other treatments. On the $65^{\text {th }}$ 
Improving Mulberry Leaf Yield and Quality to Increase Silkworm Productivity

day after pruning, significant differences were again observed on the moisture contents of leaves as affected by the different agroecosystems. The plants in the Conventional treatments and LEISA I had higher moisture contents from $1-5^{\text {th }}$ and $10-15-16-20^{\text {th }}$ positions compared with the other treatments. This implies that these treatments are more succulent and palatable to the silkworms (Fig. 7). For quality mulberry leaves for silkworm, the top leaves should have a moisture content ranging from 78 to $80 \%$ for the first and second instar, $76-77 \%$ for the third instars (ESCAP, 1993). Too soft leaves in very early stage have been found not palatable. The leaves best relished and utilized are those containing more moisture, proteins, sugars, and carbohydrates and less ash and fiber. Rearing should be done at the correct stage of leaf maturity for bulk harvest of mulberry leaves (Krishnaswami, 1990). Mulberry leaves for young silkworms must be soft, rich in water content, protein, carbohydrates, etc. Leaves which retain or contain more water and protein and have less carbohydrates and fiber contents are suitable for rearing young age silkworm larvae (Krishnaswami et al., 1987). For late age worms, higher protein content is desirable, but the leaves should not contain too much moisture. Soft and mature leaves are suitable for feeding late age worms and this could be attained when mulberry is grown in good soil optimum application of balanced fertilizer, suitable practices, and assured rainfall/irrigation (FAO, 1987; Hikari, 1997).

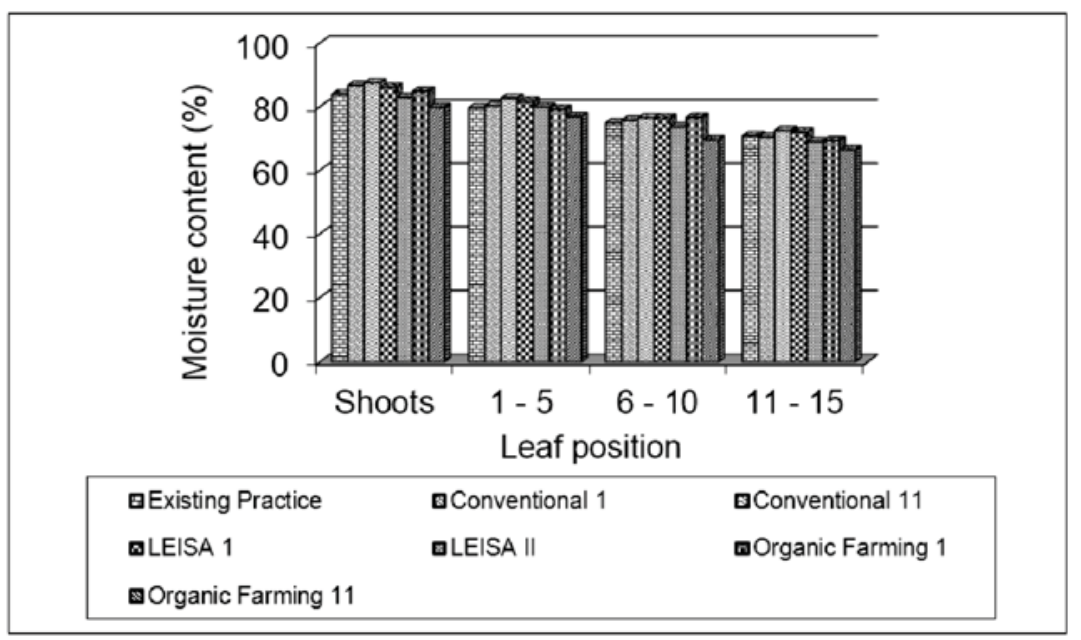

Figure 6. Moisture content of mulberry leaves as different leaf position (45DAP), Sta. Maria, Ilocos Sur, Mar-Apr 2004. 


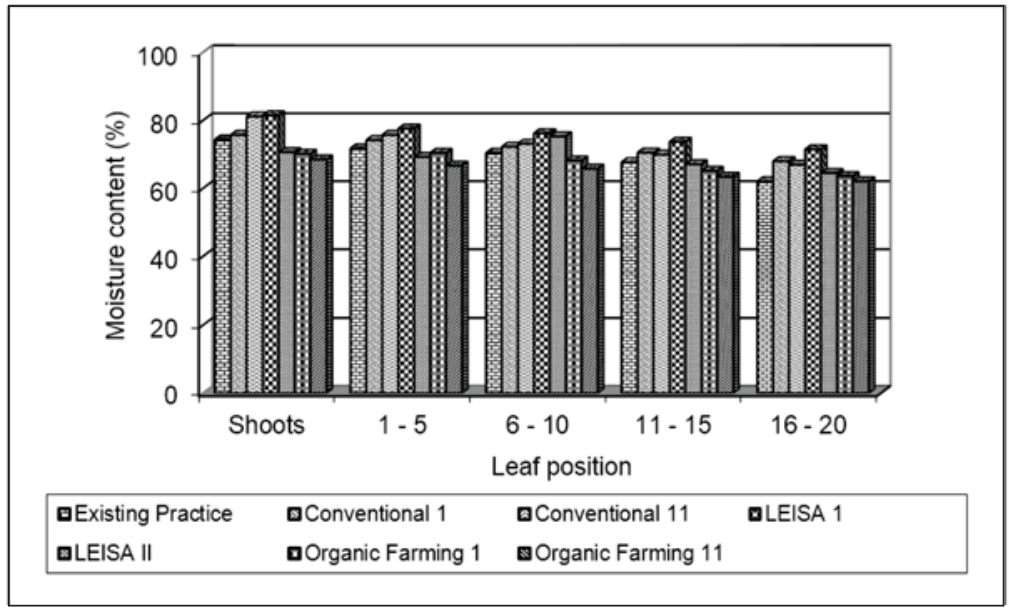

Figure 7. Moisture content of mulberry leaves at different leaf positions at 65 DAP, Sta. Maria, Ilocos Sur, Mar-Apr 2004.

\section{CONCLUSION}

The growth and yield of mulberry were significantly affected in the different agroecosystems. Pit planting of mulberry and fertilized with any of the following : 1)100-50-50 kg NPK/ha + 10 tons manure + green manure + mulch (LEISA I), 2) 50-50-50 kg NPK/ha + 10 tons manures + green + green leaf manure + mulch (LEISA II), and 3) 10 tons manure + green manure + green leaf manure + mulch (Organic Farming I) gave higher mulberry leaf yields (taller mulberry plants, longer shoots, heavier single leaf weights), higher protein contents and acceptable range of moisture (high moisture contents for young-age worms and low moisture contents for late-age silkworms), and two major leaf quality favorable for cocoon production. Applying chemical fertilizer alone as in Existing Practice proved the least effective. The use of sustainable and organic farming techniques can be a good alternative to conventional sericulture farming.

\section{ACKNOWLEDGEMENT}

The authors would like to thank PCAARRD, DA-BAR and CHED-FAPE for funding this research project. 


\section{REFERENCES}

ALTIERI, M.A. 1983. Agroecology: The Scientific Basis of Alternative Agriculture. Berkeley, Division of Biological Control. University of California.

ALVAREZ, C. 1999. The Organic Farming Sourcebook. The Other India Press, Above Mapusa Clinic, Mapusa 403507 Goa, India.

ASSOCIATION FOR INTERNATIONAL COOPERATION OF AGRICULTURE AND FORESTRY (AICAF). 1995. Sericulture in the Tropics. Association for International Cooperation of Agriculture and Forestry, Japan.

BABULAL, A.A., R.K. KATHRI SIDDIQUE And A.K SHARMA. 2005. Bivoltine cocoon production- An analysis of yield gaps and constraints. Indian Silk (2):13-14.

BADGLEY, C., MOGHTADER, J., QUINTERO, E., ZAKEM, E., CHAPPELL, M.J., AVILÉS- VÀZQUEZ, K., SAMULON, A., PERFECTO, I. (2007): Organic agriculture and the global food supply.Renewable Agriculture and Food Systems 22, 86-108.

BASILIO, C. 1995. An overview of SA Approaches and Principles. In Highlights of Proceedings in third country training program on building capacities from Asian NGOS in poverty eradication through community action "Sustainable Agriculture: A viable alternative for resource poor farmers" University Hotel, UP Diliman, Quezon City, Philippines. November 6-24, 2006.

BHOGESHA, K., P.K. DAS and L. RAJANNA. 2003. Interpreted farming in mulberry cultivation-an ecofriendly approach. Indian Silk 42 (5):5-6.

CACCAM, MABEL and T.C. MENDOZA. 2010. Factors of productivity and Profitability of Sericulture-based Agroecosystems in Region Philippines. Northern Luzon Research Journal (NRLJ) 3-4: 73-88

CHAKRABARTI, S., M.R. SUBRAMANYAM, B.K. SINGHAL AND R.K. DATTA. 1997. Nutrient deficiency management in mulberry: A key for identification of hunger signs. Central Sericulture Research and Training Institute, Mysore-8. Karnataka, India. 
CHEN, J.H., J.T. WU, and W.T. HUANG, 2001. Effects of compost on the availability of nitrogen and phosphorus in strongly acidic soils. Technical Bulletin 155, Food and Fertilizer Technology Center, Taipei, Taiwan, ROC.

COSICO, W. 2005. Primer in Soil Science. University Publication Office. University of the Philippines at Los Banos, College Laguna.

DANDIN, S.B. and H.K. BASAVARAJA. 2005. Large scale bivoltine farmingreality under tropical conditions. Indian Silk 44(2) 10-11.

ESCAP, 1993. Techniques in Silkworm Rearing in the Tropics. United Nations, New York.

FLIEßBACH, A., AND MÄDER, P. (2000): Microbial biomass and sizedensity factions differ between soils of organic and conventional agricultural systems. Soil Biology \& Biochemistry 32:757-768.

FLIEßBACH, A., OBERHOLZER, H.-R., GUNST, L., MÄDER, P. (2007): Soil organic matter and biological soil quality indicators after 21 years of organic and conventional farming. Agriculture, Ecosystems \& Environment 118, 273-284.

FOOD AND AGRICULTURE ORGANIZATION (FAO). 1987. Mulberry production Vol. 1. Manual on sericulture. National Silk Board. Bangalore, India.

FOOD AND AGRICULTURE ORGANIZATION (FAO). 1990. Sericulture training manual. Food and Agricultural Organization of the United Nations, Viadelle Terme di Caracalla, 00100 Rome, Italy.

HIKARI, Z. S. N. 1997. New Illustrated Sericulture Reader. Central Silk Board, Bangalore, India.

IFAD, IDRC, CIIFAD, ICRAF AND IIRR. 2001. Shifting cultivation: Towards sustainability and resource conservation in Asia. International fund for Agricultural Development, International Development Research center, Cornell Institute for Food, Agriculture and Development, International center for Research in Agro-forestry and International Center for Research in Agro-forestry and International Institute of Rural Reconstruction. 
Improving Mulberry Leaf Yield and Quality to Increase Silkworm Productivity

JITSANGUAN, T. 2001. Sustainable agricultural systems for small-scale farmers in Thailand: Implications for the environment. Extension Bulletin 509, Food and Fertilizer Technology Center, Taipei, Taiwan, ROC.

KRISHNASWAMI, S. 1986. Mulberry cultivation in South India. Central Sericultural Research and Training Institute, Mysore India.

KRISHNASWAMI, S. 1990. New technology in silkworm rearing. Central Sericultural Research and Training Institute, Mysore India.

KUMAR, N.S., N.K. BASAVARAJA and S.B. DANDIN. 2004. Breeding of robust bivoltine silkworm (Bombyx mori L.) for temperature tolerance - A review. Indian Journal of Sericulture 43(2): 111-124.

MANSATTA, B. 1999. Bhaskar Save: Trench Farming. In Alvares Claude, 1999. The Organic Farming sourcebook. The Other India press, Above Mapusa Clinic, Mapusa 403507 Goa, India

NATIONAL SERICULTURE AND ENTOMOLOGY RESEARCH INSTITUTE (NSERI). 1996. Principles and practices in sericulture. National Sericulture and Entomology Research Institute, Rural Development Administration. Suwon, South Korea.

NIGGLI, U., FLIEßBACH, A., HEPPERLY, P. AND SCIALABBA, N. 2009. Low Greenhouse Gas Agriculture: Mitigation and Adaptation Potential of Sustainable Farming Systems. FAO, April 2009, Rev. 2 - 2009.

PHILIPPINE COUNCIL FOR AGRICULTURE, AQUATIC AND NATURAL RESOURCES RESEARCH AND DEVELOPMENT. Organic Agriculture in the Philippines-A Training Manual. Los Banos, Laguna:PCAARRD-DOST, 2012 443pp-(PCAARRD Training Module No 4(2012).

PIMENTEL, D., HEPPERLY, P., HANSON, J., DOUDS, D., SEIDEL, R. (2005): Environmental, energetic, and economic comparisons of organic and conventional farming systems. Bioscience 55: 573-582.

PIMENTEL, D.; HARVEY, C.; RESOSUDARMO, P.; SINCLAIR, K.; KURZ, D.; MCNAIR, M.; CRIST, S.;SHPRITZ, L.; FITTON, L.; SAFFOURI; R. \& BLAIR; R. (1995). Environmental and Economic Costs of Soil Erosion and Conservation Benefits. Science, 267:1117-1123. 
REIJNTJES, C., B. HAVERTKORT, and A.W. BAYER. 1992. Farming for the Future. An Introduction to Low-External-Input and Sustainable Agriculture. McMillan Press Ltd, ILEIA. P.O. Box 64, NL-3830 AB Leusden, Netherlands.

REGANOLD, J.P.; ELLIOT, L.F. AND UNGER, Y.L. (1987). Long-term effects of organic and conventional farming on soil erosion. Nature 330:370372.

SANCHEZ, MANUEL. 2000. Mulberry: An exceptional forages available almost worldwide! World Animal Review, 2000, 93(1), FAO Rome.

SINGH, A.K., J.S. BISEN, D.K. BORA, R. KUMAR and B. BERA. 2011. Comparative study of organic, inorganic and integrated plant nutrient supply on the yield of Darjeeling tea and soil health, Tea and a Bud, 58$61,2011$.

SMITH, P., D. MARTINO, Z. CAI, D. GWARY, H. JANZEN, P. KUMAR, B. MCCARL, S. OGLE, F. O'MARA, C. RICE, B. SCHOLES, O. SIROTENKO (2007): AGRICULTURE. In Climate Change (2007): Mitigation. Contribution of Working Group III to the Fourth Assessment Report of the Intergovernmental Panel on Climate Change [B. Metz, O.R. Davidson, P.R. Bosch, R. Dave, L.A. Meyer (eds)], Cambridge University Press, Cambridge, United Kingdom and NewYork, NY, USA. Available at http://www.mnp.nl/ipcc/pages_media/FAR4docs/final_pdfs_ar4/Ch apter08.pdf

THORUP-KRISTENSEN, K., MAGID, J. AND JENSEN, L.S. (2003) Catch crops and green manures as biological tools in nitrogen management in temperate zones. Advances in Agronomy 79: 227302.

UNITED NATIONS DEVELOPMENT PROGRAM (UNDP). 1995. Agroecology. Creating synergism for a sustainable agriculture. UNDP Guidebook Series. On United Nations Plaza FF10344 New York. 
Improving Mulberry Leaf Yield and Quality to Increase Silkworm Productivity

WILLIAMS, A.N. and W. GRAHAM. 1998. The farmers' guide to alternative farming techniques. ACT Press, ACT-Dominica 5 Marlborough St. Roseau Commonwealth of Dominica. 